DOI: 10.17707/AgricultForest.62.2.11

\author{
Elnesr, M. N, Alazba, A. A., \\ El-Hagary, M. E. ${ }^{1}$
}

\title{
EFFECTS OF WATER DEFICIT AND APPLICATION METHOD, ON DRIP IRRIGATED PEACH
}

\section{SUMMARY}

A 2-year study was conducted to determine the effects of different drip irrigation profiles on the yield quantity and quality of mature peach trees [Prunus persica L.]. The irrigation profiles were the combination of emitter location (ground drip or subsurface buried @ $15 \mathrm{~cm}$ ), emission rate (conventional $4.0 \mathrm{~L} \mathrm{~h}^{-1}$ or low-flow $\left.0.5 \mathrm{~L} \mathrm{~h}^{-1}\right)$, and water deficiency level $(60 \%, 80 \%, 100 \%$ of ET). The results showed that yield and water use efficiency (WUE) were not affected by the irrigation profiles, while there were some reduction in the yield and improvement in WUE due to water 60\% ET deficiency application. On the other hand, some of the fruit quality measures (Total sugars, and maturity index) were affected by the irrigation profile as the low-flow profiles yielded sweeter and more matured fruits. Moreover, the study involved water and salt measurements under each irrigation profile, the conventional drip rate showed more-efficient salt flushing, while the low-flow profiles showed wider lateral movement of water. The best overall treatment under average conditions was the low-flow ground drip with $80 \%$ of ET.

Keywords: Low-flow; ultra-low flow drip; drip irrigation system; deficit irrigation; irrigation profiles; peach fruit quality; subsurface drip irrigation.

\section{INTRODUCTION}

The peach tree is a deciduous tree that bears a nutritious and aromatic juicy fruit. Although the second part of its binomial name, Prunus persica, refer to Persia; its origin refers to Northwest China where it was grown more than 30 centuries ago. China remains the largest peach producer till now (Faust and Timon, 1995; Zarini, 2014). Peach production has a growing economic importance worldwide, the most considerable economic factors are yield quantity and quality, earlier crop production, less plant stress and reduced yield variability (Cetin et al., 2003; Zarini, 2014). Proper irrigation management is very important for peach to maintain healthy growth and acceptable productivity even in areas with relatively high rainfall (Bryla et al., 2005; Williamson and Crane, 2010).

\footnotetext{
${ }^{1}$ Elnesr, M. N, Alamoudi Chair for Water Research, King Saud University, SAUDI ARABIA, Soil and Water Conservation Department, Desert Research Center, EGYPT (corresponding author: melnesr@ksu.edu.sa), Alazba, A. A. Alamoudi Chair for Water Research, King Saud University, SAUDI ARABIA, Agricultural Engineering Department, King Saud University, SAUDI ARABIA, El-Hagary, M. E, Soil and Water Conservation Department, Desert Research Center, EGYPT Notes: The authors declare that they have no conflicts of interest. Authorship Form signed online.
} 
Peach is irrigated by almost all the irrigation methods including furrows, borders, micro-sprinklers, and drip irrigation systems, however, the production and growth of the peach trees is significantly affected by the irrigation method especially in the first 3 years of their age (Bryla et al., 2003). Several studies showed that drip irrigation resulted in better fruit quality, greater quantity, and earlier production (Bryla et al., 2005, 2003; Cetin et al., 2003). Additionally, applying drip irrigation using extremely low flow rates $\left(<1.0 \mathrm{~L} \mathrm{~h}^{-1}\right)$ enhances water lateral-spread, reduces water losses by evaporation and deep percolation, and increase the water use efficiency (Abdou et al., 2010; Gilead, 2002; Mead, 2001). To conserve water, some investigators applied several deficit irrigation strategies and/or irrigation scheduling methods on drip irrigated peach, they reported a significant response to the deficit irrigation strategies and negligible effect of the scheduling methods (Araguiés et al., 2014; Goldhamer et al., 2001). When applied on peach trees, deficit irrigation led to improved fruit quality and increased soluble solid content (Pliakoni and Nanos, 2010), but it lead to yield reduction to some extent (Abrisqueta et al., 2010; Rufat et al., 2010), and increased water use efficiency (Abrisqueta et al., 2010). The aim of this work is to study the effect of dripper flow rate, dripper location, and water deficiency ratio on the yield quantity and quality of drip-irrigated peach trees.

\section{Study site}

\section{MATERIAL AND METHODS}

The field experiments were conducted in an experimental farm located at Badr City, Northwestern of Cairo, Egypt (30 30' 44” N, 30 27' 17' E). The experiments were carried out through two successive seasons 2012 and 2013 on seven years old Florida prince peach trees budded onto Nemaguard rootstocks. The trees were planted at distance of $5 \mathrm{~m}$ between rows, and $4 \mathrm{~m}$ within rows in a sandy soil; the properties of the soil are listed in Table 1 . The field was irrigated by water pumped from an $80 \mathrm{~m}$ deep well; the chemical properties of it are listed in the same table.

Table 1. Physical and chemical properties of soil and water

\begin{tabular}{|c|c|c|c|c|c|c|c|}
\hline \multicolumn{10}{|c|}{ Physical properties (of soil) } \\
\hline $\begin{array}{c}\text { Soil } \\
\text { Dept }\end{array}$ & $\begin{array}{c}\text { Course } \\
\text { sand }\end{array}$ & $\begin{array}{c}\text { Fine } \\
\text { sand }\end{array}$ & $\begin{array}{c}\text { Sil } \\
\mathrm{t}\end{array}$ & $\begin{array}{c}\text { Cla } \\
\mathrm{y}\end{array}$ & $\begin{array}{c}\text { Field } \\
\text { capacity }\end{array}$ & $\begin{array}{c}\text { wilting } \\
\text { point }^{1}\end{array}$ & $\begin{array}{c}\text { Bulk } \\
\text { density }\end{array}$ \\
\hline $\mathrm{cm}$ & $\%$ & $\%$ & $\%$ & $\%$ & $\%$ & $\%$ & g.cm $^{-3}$ \\
\hline $0-30$ & 92.8 & 3.7 & 2.0 & 1.5 & 10 & 4.8 & 1.83 \\
\hline $30-60$ & 91.5 & 1.8 & 0.2 & 6.5 & 11 & 6.3 & 1.79 \\
\hline $60-90$ & 93.1 & 0.6 & 0.4 & 5.9 & 13 & 5.5 & 1.72 \\
\hline
\end{tabular}

*properties are measured in $\%$ by volume. 


\begin{tabular}{|c|c|c|c|c|c|c|c|c|c|}
\hline \multicolumn{10}{|c|}{ Chemical properties } \\
\hline $\mathrm{pH}$ & $\mathrm{EC}^{2}$ & \multicolumn{4}{|c|}{ Soluble Cations, $\mathrm{mg} \mathrm{L}^{-1}$} & \multicolumn{4}{|c|}{ Soluble Anions, $\mathrm{mg} \mathrm{L}^{-1}$} \\
\hline & dS.m ${ }^{-1}$ & $\mathrm{Ca}^{++}$ & $\mathrm{Mg}^{++}$ & $\mathrm{Na}^{+}$ & $\mathrm{K}^{+}$ & $\mathrm{CO}_{3}^{-}$ & $\mathrm{HCO}_{3}^{-}$ & $\mathrm{SO}_{4}^{--}$ & $\mathrm{Cl}^{-}$ \\
\hline \multicolumn{10}{|c|}{...of Soil } \\
\hline 8.8 & 2.80 & 9.10 & 9.60 & 8.61 & 0.69 & - & 2.34 & 12.06 & 13.6 \\
\hline 8.4 & 0.21 & 0.82 & 0.28 & 0.80 & 0.20 & - & 0.73 & 0.47 & 0.9 \\
\hline 8.8 & 0.76 & 1.80 & 1.28 & 3.65 & 0.84 & - & 1.47 & 2.50 & 3.6 \\
\hline \multicolumn{10}{|c|}{...of Water } \\
\hline 6.9 & 1.634 & 2.55 & 1.61 & 11.9 & 0.28 & - & 2.25 & 2.79 & 11.3 \\
\hline
\end{tabular}

* EC is measured in the saturation extract

\section{Experimental design}

The trees were irrigated using four methods; the methods include two types of emitters; conventional emitters $\left(\mathrm{C}, 4.0 \mathrm{~L} \mathrm{~h}^{-1}\right)$, and low flow emitters (L, $\left.0.5 \mathrm{~L} \mathrm{~h}^{-1}\right)$, and two locations of the lateral lines; ground drip $(\mathrm{G})$, and subsurface drip (S) at $15 \mathrm{~cm}$ depth. The four possible combinations between them are GC, SC, GL, and SL. Each of these combinations were applied using three levels of deficiency $40,20,0 \%\left(60,80\right.$, and $100 \%$ of the calculated $\mathrm{ET}_{c},\left\{\mathrm{D}_{4}, \mathrm{D}_{2}\right.$, and $\mathrm{D}_{0}$ respectively $\})$. Each treatment combination $\left(\mathrm{GC} \times \mathrm{D}_{4}\right.$ for example) was applied on 6 random trees. The total number of trees was 72 trees ( 3 deficiency levels $\times 4$ irrigation methods $\times 6$ replications).

\section{Irrigation management and water calculations}

The used pumping plant consisted of a centrifugal pump with maximum discharge of $80-\mathrm{m}^{3} \mathrm{~h}^{-1}$ driven by a diesel engine $37 \mathrm{~kW}$ with a maximum lift of $20 \mathrm{~m}$. We used two types of emitters; one for the $\mathrm{C}$ treatments and one for the $\mathrm{L}$ treatments. For the $\mathrm{C}$ treatments we used built in emitters with $4 \mathrm{~L} \mathrm{~h}^{-1}$ discharge, while for the $\mathrm{L}$ treatments we used $2 \mathrm{~L} \mathrm{~h}^{-1}$ multi-exit emitters (Table 2), with an attached five-way manifold of a female inlet and four outlet barbs with spaghetti tubes installed on each barb emitting $0.5 \mathrm{~L} \mathrm{~h}^{-1}$

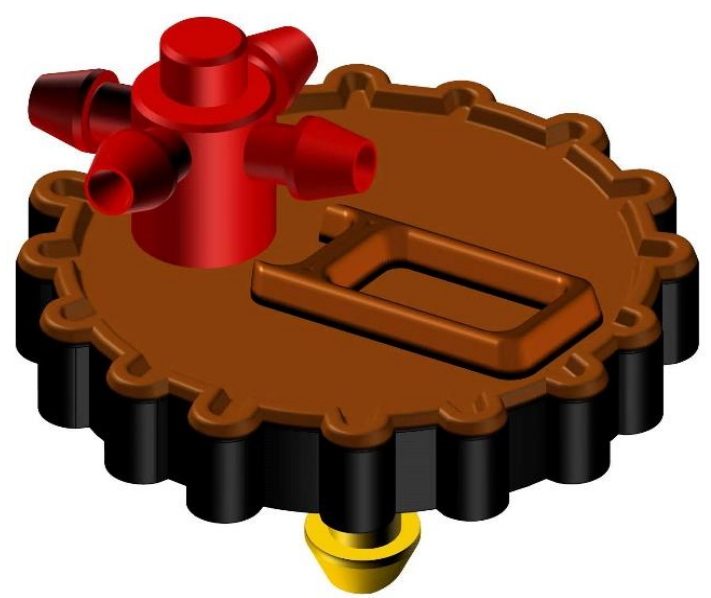

Fiure 1. An illustration of the on-line emitter with a manifold plugin that is used for low flow irrigation. The emitter's outflow is $2 \mathrm{~L} / \mathrm{h}$ resulting in $0.5 \mathrm{~L} / \mathrm{h}$ per outlet 
For the $\mathrm{C}$ treatments 16 emitters were used for each tree placed $0.5 \mathrm{~m}$ apart in two laterals around the tree trunk totaling $32 \mathrm{~L} \mathrm{~h}^{-1}$. While for the $\mathrm{L}$ treatments, two multi-exit emitter were used per tree, where the spaghettis encircle the trunk of the tree totaling $8 \mathrm{~L} \mathrm{~h}^{-1}$. The operating time of the $\mathrm{L}$ treatments was always set to be 4 times as the $\mathrm{C}$ treatments of the same deficiency level.

To measure the effectiveness of the irrigation methods, we calculated the water use efficiency (WUE), which is the ratio between the yield and the applied water, $\mathrm{kg} / \mathrm{m}^{3}$, it is a good indicator of the effective water management and successful irrigation practices (Doorenbos and Pruitt, 1977; Kang et al., 2000; Rahil and Qanadillo, 2015).

\section{Orchard management}

Irrigation water requirements for peach trees were calculated according to daily climatic data from the local weather station data belonged to the Central Laboratory for Agricultural Climate (CLAC). The water requirements were calculated on daily basis using the FAO-56 methodology (Allen et al., 1998). The reference evapotranspiration $\left(\mathrm{ET}_{\mathrm{o}}\right)$ values were calculated daily based on measured climatic data, while we took the crop coefficient $\left(k_{c}\right)$ values from the local agriculture extension services. The kc values for the initial, middle, and late stages were $0.48,0.79$, and 0.75 respectively. Due to its rarity in the study region, the active rain is negligible, the seasonal irrigation requirement according to Nakayama and Bucks (2012) recommendations were $5781.4 \mathrm{~m}^{3} \mathrm{ha}^{-1}$ (Table 2)

Table 2. Seasonal water requirements of peach trees.

\begin{tabular}{|c|c|c|c|c|c|c|}
\hline \multirow{2}{*}{$\begin{array}{l}\text { Grow } \\
\text { th } \\
\text { stage }\end{array}$} & \multirow[t]{2}{*}{$\begin{array}{c}\text { Mon } \\
\text { th }\end{array}$} & $\begin{array}{c}\text { Reference } \\
\text { Evapotranspira } \\
\text { tion }\left(\mathrm{ET}_{0}\right)\end{array}$ & \multirow{2}{*}{$\begin{array}{l}\text { Crop } \\
\text { Coeffici } \\
\text { ent }\left(K_{c}\right)\end{array}$} & $\begin{array}{c}\text { Crop } \\
\text { Evapotranspira } \\
\text { tion }\left(\mathrm{ET}_{\mathrm{c}}\right)\end{array}$ & $\begin{array}{c}\text { Daily } \\
\text { water } \\
\text { requireme }\end{array}$ & $\begin{array}{c}\text { Water } \\
\text { requireme } \\
\text { nts per }\end{array}$ \\
\hline & & $\mathrm{mm} /$ day & & $\mathrm{mm} /$ day & L/day & $\mathrm{m}^{3} / \mathrm{ha} / \mathrm{day}$ \\
\hline \multirow{3}{*}{$\begin{array}{c}\text { Initia } \\
1\end{array}$} & Jan. & 2.4 & 0.48 & 1.152 & 11.5 & 5.8 \\
\hline & Feb. & 3.2 & 0.48 & 1.536 & 15.4 & 7.7 \\
\hline & Mar. & 4.2 & 0.48 & 2.016 & 20.2 & 10.1 \\
\hline \multirow{4}{*}{$\begin{array}{c}\text { Midd } \\
\text { le }\end{array}$} & Apr. & 5.6 & 0.79 & 4.424 & 44.2 & 22.2 \\
\hline & May & 6.6 & 0.79 & 5.214 & 52.1 & 26.2 \\
\hline & Jun. & 7.3 & 0.79 & 5.767 & 57.7 & 28.9 \\
\hline & Jul. & 7.2 & 0.79 & 5.688 & 56.9 & 28.5 \\
\hline \multirow{2}{*}{ Late } & Aug. & 6.7 & 0.75 & 5.025 & 50.3 & 25.2 \\
\hline & Sep. & 5.6 & 0.75 & 4.200 & 42.0 & 21.1 \\
\hline
\end{tabular}

The irrigation starts at January and ends in September, with 2-3 weekly irrigations. The time of each irrigation depends on the irrigation treatment, the deficiency level, and the average calculated $\mathrm{ET}_{\mathrm{c}}$ in this week (which combines weather conditions and phenological stage).

According to the recommendations of the local extension services, the fertilization program was applied to the trees through traditional application methods (no fertigation), and the weeds and pests were controlled. 


\section{Soil measurements}

To determine soil water content and salt accumulation, we took soil samples manually using a screw auger. At each location, we took twelve samples, (At 4 depths $\times 3$ perpendicular distances). The sampling depths were at locations $0-20,20-40,40-60$, and $60-80 \mathrm{~cm}$ below soil surface, while the perpendicular distances were at $10,30,50 \mathrm{~cm}$ perpendicular to the lateral line. At the beginning, middle and end of each season, soil samples were taken at four timings; before irrigation, 2, 10, and 18 hours after irrigation. According to the method of Gardner (1986) we measured the gravimetric water content in the samples, then the samples were air-dried and sieved to calculate the electrical conductivity (EC, $\mathrm{dS} \mathrm{\textrm {m } ^ { - 1 }}$ ) in the saturation extract (Germaine and Germaine, 2009). The total soluble salts (TSS, ppm) values were calculated by multiplying the EC by 640 (Sonon et al., 2012). The results of water and salts distribution were interpolated using the kriging method (Abramowitz and Stegun, 2012), and then were plotted using Surfer software, (Golden Software v.9).

\section{Crop measurements:}

In addition to the yield of each tree that was quantified at the end of each season, additional fruit quality measures were performed on a representative sample of 20 mature fruits from each considered treatment. These measurements taken were: the fruit total weight and pulp weight, dimensions and volume, in addition to some chemical characteristics in juice like the total soluble solids percentage (TSS\%) determined using hand refractometer, titratable acidity percentage (TA\%, as malic acid, $1 \%$ total acidity $=10 \mathrm{~g}$ malic acid per Liter of juice) following the methods of Cunniff (1999), and the total sugars \% was identified by the methods described by Brooks et al (1993), accordingly, the Maturity index (MI) was calculated as 10xTSS/TA (Conesa et al., 2014). When the MI ratio is high, the overall flavor of the fruit becomes flat, and the fruit becomes tasteless (Shinya et al., 2014). The ripen fruits were taken according to the signs described at Kader (1999).

On the other hand, we have measured some leaf characteristics like the surface area, chlorophyll and NPK contents. The leaf area was measured using 20 mature leaves as the third one of the base of the previously tagged non-fruiting shoots from spring cycle were taken randomly from each replicate at mid-June, then measured by the planimeter. The leaf total chlorophyll content was estimated in the field by using SPAD-502 meter (Minolta Co., and Osaka). To estimate the leaf NPK content, we collected 20 matures leaves, at first week of July each season, from the middle portion of current year shoots of each replicate, leaves were collected to determine macro elements in dry leaf samples, nitrogen percentage was estimated by micro-Kjeldahl method (Steyermark, 1961), phosphorous percentage was determined using atomic absorption spectrophotometer Perken Elmer (Model 3300, USA) according to Chapman and Pratt (1961), and potassium was estimated according to Brown and Lilleland (1966). 


\section{Statistical analysis}

The obtained results were statistically analyzed using Statistix v.10.0, Analytical Software. Where the factorial linear model was used for analysis of variance. The first factor was the irrigation profile in four levels, and the second factor was the deficiency level in three levels. Means were separated at 0.05 level using Tukey's honest significant difference test (HSD).

\section{RESULTS AND DISCUSSION}

Plant results. According to the statistics in Table 3, if a studied property showed only single effects significance, i.e. the interaction DL $\times$ IR is not significant, then the results will be discussed according to the single effects' means, Table 4, otherwise the results will be discussed according to the interaction means, Table 5.

Table 3. Statistical significance of the irrigation profile, the deficiency level, and their interaction

\begin{tabular}{|c|c|c|c|c|c|c|}
\hline & \multicolumn{3}{|c|}{ Year 1} & \multicolumn{3}{|c|}{ Year 2} \\
\hline & DL & IR & DL $\times$ IR & DL & IR & DL $\times I R$ \\
\hline Yield (kg/tree) & $* *$ & $* *$ & --- & $* *$ & --- & --- \\
\hline Water use efficiency $(\mathrm{kg} / \mathrm{m} 3)$ & $* *$ & $* *$ & $* *$ & $* *$ & --- & --- \\
\hline \multicolumn{7}{|l|}{ Fruit measures: } \\
\hline Fruit weight (g) & $* *$ & $* *$ & $* *$ & $* *$ & $* *$ & $* *$ \\
\hline Fruit height $(\mathrm{cm})$ & --- & $* *$ & $* *$ & --- & $* *$ & $* *$ \\
\hline Fruit diameter $(\mathrm{cm})$ & $* *$ & $*$ & $* *$ & $* *$ & --- & $* *$ \\
\hline Fruit volume $(\mathrm{cm} 3)$ & --- & $* *$ & $*$ & $* *$ & $* *$ & $* *$ \\
\hline Flesh thickness $(\mathrm{cm})$ & $* *$ & $*$ & $* *$ & $* *$ & $*$ & $* *$ \\
\hline Flesh weight (g) & $* *$ & $* *$ & $* *$ & $* *$ & $* *$ & $* *$ \\
\hline \multicolumn{7}{|l|}{ Leaf measures: } \\
\hline Leaf area $\left(\mathrm{cm}^{2}\right)$ & $* *$ & $* *$ & $* *$ & $* *$ & $* *$ & $*$ \\
\hline Chlorophyll content (\%) & $* *$ & $* *$ & $*$ & $* *$ & $* *$ & --- \\
\hline Nitrogen leaf content, N (\%) & $* *$ & $* *$ & $* *$ & $* *$ & $* *$ & $* *$ \\
\hline Phosphorus leaf content, $\mathrm{P}(\%)$ & $* *$ & $* *$ & $* *$ & $* *$ & $* *$ & $* *$ \\
\hline Potassium leaf content, K (\%) & $* *$ & $* *$ & $* *$ & $* *$ & $* *$ & $* *$ \\
\hline \multicolumn{7}{|l|}{ Juice measures: } \\
\hline $\operatorname{TSS}(\%)$ & $* *$ & $*$ & --- & --- & $* *$ & $*$ \\
\hline Total acidity, TA $(\%)$ & $* *$ & $* *$ & --- & $* *$ & $* *$ & $* *$ \\
\hline Maturity index, MI (-) & --- & $* *$ & --- & $* *$ & $* *$ & --- \\
\hline Total sugars, TSG (g/100cc) & $* *$ & $* *$ & $*$ & $* *$ & $* *$ & --- \\
\hline
\end{tabular}


In general, as shown in Table 3. we found that the single effects of both the deficiency level (DL) and the irrigation profile (IR) led to significant differences in almost all of the studied measures in the two years, while the interaction between them showed significance in fruit and leaf measures, but not in the juice measures

Yield and water use efficiency. For the yield, Table 3 showed that the interaction between IR and DL (IR $\times$ DL) is not significant in the two years; hence, we can analyze the single effect of each factor individually. For the water use efficiency (WUE), the table showed that the IR $\times$ DL was significant in the first year; hence, we will compare the means of the combination treatments, Table 5, while only the DL is significant in the second year.

The effect of the deficiency level appears on Table 4. The results showed that the increase in water deficiency leads to decrease in yield; the average yield of peach with no deficiency (D0) was $22.7 / 22.4 \mathrm{~kg} /$ tree for year $1 /$ year 2 respectively (22.55 in average). The average values were 22.25 and $20.05 \mathrm{~kg} / \mathrm{tree}$ for $20 \%$ (D2) and 40\% (D4) deficiency levels respectively, where there were no significant difference between D0 and D2. The WUE was solely affected by the DL in the second year, where the highest WUE value was the D4 followed by the D2 then D0 $(2.91,2.33$, and $1.93 \mathrm{~kg} / \mathrm{m} 3$ respectively, $(50.7 \%$, and $20.7 \%$ for D4 and D2 over D0 respectively)

Looking at the irrigation profiles effects, Table 4; we found that in the first year, the low flow treatments (GL and SL) returned higher yields than the conventional treatments (GC and SC), while the effect of the irrigation profile is not significant at the second year.

The interaction between IR $\times$ DL affected only the WUE in the first year, Table 5 showed that the highest WUE was from the GL-D4 treatment combination, with $3.4 \mathrm{~kg} / \mathrm{m} 3$ followed by the SL-D4 treatment $(3.0 \mathrm{~kg} / \mathrm{m} 3)$, while the least WUE was $1.9 \mathrm{~kg} / \mathrm{m} 3$ from the GC-D0 and SC-D0 treatments. The treatments GL-D4 and SL-D4 were the top in water saving in the second year as well.

Fruit measures. Looking at Table 3, we can notice that excluding the fruit height and volume, all the fruit measures were significantly affected by the DL and by the interaction DLXIR. The heaviest fruit average, Table 5 , in the first year was $72.2 \mathrm{~g}$ for the control treatment GC-D0, which yielded $85.8 \mathrm{~g}$ fruits in the second year with no significant difference of the SC-D0 treatment $(89 \mathrm{~g})$. Similarly, the maximum diameter, maximum flesh thickness and weight were obtained at the control treatment GC-D0 in the two years. Furthermore, it is noticed that the fruit weight of the treatments with deficiency applied was significantly less than that of the control treatments in the two years, and the fruit diameter follows the same trend. However, the results showed that regarding the flesh thickness, the D2 treatment had no significant difference than the D0 treatment, while the D4 treatment led to significantly thinner flesh. 
Table 4. Means of single effects of the irrigation profile and the deficiency level

\begin{tabular}{|c|c|c|c|c|c|c|c|}
\hline & \multicolumn{3}{|c|}{ Deficiency level } & \multicolumn{4}{|c|}{ Irrigation profile } \\
\hline Year 1 & D0 & D2 & D4 & GC & GL & SC & SL \\
\hline Yield (kg/tree) & $22.73 \mathrm{a}$ & $22.59 \mathrm{a}$ & $20.26 \mathrm{~b}$ & $19.83 \mathrm{C}$ & $24.95 \mathrm{~A}$ & $20.38 \mathrm{C}$ & $22.28 \mathrm{~B}$ \\
\hline Water use efficiency $(\mathrm{kg} / \mathrm{m} 3)$ & $2.03 \mathrm{c}$ & $2.44 \mathrm{~b}$ & $2.91 \mathrm{a}$ & $2.28 \mathrm{C}$ & $2.76 \mathrm{~A}$ & $2.27 \mathrm{C}$ & $2.53 \mathrm{~B}$ \\
\hline \multicolumn{8}{|c|}{ Fruit measures: } \\
\hline Fruit weight (g) & $70.2 \mathrm{a}$ & $65.1 \mathrm{~b}$ & $65.2 \mathrm{~b}$ & $68.2 \mathrm{~A}$ & $67.4 \mathrm{~A}$ & $64.3 \mathrm{~B}$ & $67.3 \mathrm{~A}$ \\
\hline Fruit height $(\mathrm{cm})$ & $4.81 \mathrm{a}$ & $4.81 \mathrm{a}$ & $4.72 \mathrm{a}$ & $4.80 \mathrm{AB}$ & $4.68 \mathrm{~B}$ & $4.76 \mathrm{AB}$ & $4.88 \mathrm{~A}$ \\
\hline Fruit diameter $(\mathrm{cm})$ & $5.17 \mathrm{a}$ & $5.01 \mathrm{~b}$ & $4.81 \mathrm{c}$ & $4.99 \mathrm{AB}$ & $5.02 \mathrm{AB}$ & $4.94 \mathrm{~B}$ & $5.05 \mathrm{~A}$ \\
\hline Fruit volume $\left(\mathrm{cm}^{3}\right)$ & $52.3 \mathrm{a}$ & $54.3 \mathrm{a}$ & $53.0 \mathrm{a}$ & $57.4 \mathrm{~A}$ & $56.3 \mathrm{~A}$ & $43.9 \mathrm{~B}$ & $55.0 \mathrm{~A}$ \\
\hline Flesh thickness $(\mathrm{cm})$ & $1.55 \mathrm{a}$ & $1.55 \mathrm{a}$ & $1.45 \mathrm{~b}$ & $1.52 \mathrm{AB}$ & $1.55 \mathrm{~A}$ & $1.48 \mathrm{~B}$ & $1.52 \mathrm{AB}$ \\
\hline Flesh weight $(\mathrm{g})$ & $62.2 \mathrm{a}$ & $56.9 \mathrm{~b}$ & $57.1 \mathrm{~b}$ & $60.1 \mathrm{~A}$ & $59.2 \mathrm{~A}$ & $56.3 \mathrm{~B}$ & $59.3 \mathrm{~A}$ \\
\hline \multicolumn{8}{|c|}{ Leaves measures: } \\
\hline Leaf area $(\mathrm{cm} 2)$ & $35.91 \mathrm{a}$ & $35.84 \mathrm{a}$ & $34.67 \mathrm{~b}$ & $33.31 \mathrm{C}$ & $37.03 \mathrm{~A}$ & $34.92 \mathrm{~B}$ & $36.63 \mathrm{~A}$ \\
\hline Chlorophyll content (\%) & $35.94 \mathrm{a}$ & $35.67 \mathrm{a}$ & $34.83 \mathrm{~b}$ & $34.02 \mathrm{C}$ & $37.06 \mathrm{~A}$ & $35.29 \mathrm{~B}$ & $35.56 \mathrm{~B}$ \\
\hline Nitrogen leaf content, N (\%) & $2.482 \mathrm{c}$ & $2.723 \mathrm{a}$ & $2.609 \mathrm{~b}$ & $2.472 \mathrm{C}$ & $2.757 \mathrm{~A}$ & $2.580 \mathrm{~B}$ & $2.610 \mathrm{~B}$ \\
\hline Phosphorus leaf content, $\mathrm{P}(\%)$ & $0.163 \mathrm{c}$ & $0.201 \mathrm{a}$ & $0.183 \mathrm{~b}$ & $0.111 \mathrm{C}$ & $0.238 \mathrm{~A}$ & $0.192 \mathrm{~B}$ & $0.187 \mathrm{~B}$ \\
\hline Potassium leaf content, K (\%) & $1.159 \mathrm{~b}$ & $1.202 \mathrm{a}$ & $1.167 \mathrm{~b}$ & $1.109 \mathrm{C}$ & $1.217 \mathrm{~A}$ & $1.170 \mathrm{~B}$ & $1.207 \mathrm{~A}$ \\
\hline \multicolumn{8}{|c|}{ Juice measures: } \\
\hline TSS $(\%)$ & $10.68 \mathrm{~b}$ & $11.71 \mathrm{a}$ & $11.85 \mathrm{a}$ & $11.79 \mathrm{~A}$ & $11.00 \mathrm{~B}$ & $11.53 \mathrm{AB}$ & $11.33 \mathrm{AB}$ \\
\hline Total acidity, TA (\%) & $0.78 \mathrm{~b}$ & $0.84 \mathrm{a}$ & $0.85 \mathrm{a}$ & $0.98 \mathrm{~A}$ & $0.74 \mathrm{C}$ & $0.81 \mathrm{~B}$ & $0.76 \mathrm{BC}$ \\
\hline Maturity index, MI (-) & $13.90 \mathrm{a}$ & $14.13 \mathrm{a}$ & $14.04 \mathrm{a}$ & $12.09 \mathrm{~B}$ & $14.79 \mathrm{~A}$ & $14.32 \mathrm{~A}$ & $14.90 \mathrm{~A}$ \\
\hline Total sugars, TSG $(\mathrm{g} / 100 \mathrm{cc})$ & $4.03 \mathrm{ab}$ & $4.18 \mathrm{a}$ & $3.91 \mathrm{~b}$ & $3.82 \mathrm{~B}$ & $4.49 \mathrm{~A}$ & $3.86 \mathrm{~B}$ & $3.99 \mathrm{~B}$ \\
\hline Year 2 & D0 & D2 & D4 & GC & GL & SC & SL \\
\hline Yield (kg/tree) & $22.44 \mathrm{a}$ & $21.93 \mathrm{a}$ & $19.76 \mathrm{~b}$ & $20.96 \mathrm{~A}$ & $20.95 \mathrm{~A}$ & $21.47 \mathrm{~A}$ & $22.13 \mathrm{~A}$ \\
\hline Water use efficiency $(\mathrm{kg} / \mathrm{m} 3)$ & $1.93 \mathrm{c}$ & $2.33 \mathrm{~b}$ & $2.91 \mathrm{a}$ & $2.30 \mathrm{~A}$ & $2.34 \mathrm{~A}$ & $2.40 \mathrm{~A}$ & $2.52 \mathrm{~A}$ \\
\hline \multicolumn{8}{|c|}{ Fruit measures: } \\
\hline Fruit weight (g) & $82.2 \mathrm{a}$ & $72.6 \mathrm{~b}$ & $73.2 \mathrm{~b}$ & $76.1 \mathrm{~B}$ & $73.7 \mathrm{C}$ & $79.2 \mathrm{~A}$ & $75.0 \mathrm{BC}$ \\
\hline Fruit height $(\mathrm{cm})$ & $5.28 \mathrm{a}$ & $5.24 \mathrm{a}$ & $5.20 \mathrm{a}$ & $5.17 \mathrm{~B}$ & $5.08 \mathrm{~B}$ & $5.35 \mathrm{~A}$ & $5.35 \mathrm{~A}$ \\
\hline Fruit diameter $(\mathrm{cm})$ & $5.46 \mathrm{a}$ & $5.22 \mathrm{~b}$ & $5.11 \mathrm{c}$ & $5.23 \mathrm{~A}$ & $5.27 \mathrm{~A}$ & $5.30 \mathrm{~A}$ & $5.25 \mathrm{~A}$ \\
\hline Fruit volume $\left(\mathrm{cm}^{3}\right)$ & $81.7 \mathrm{a}$ & $67.0 \mathrm{c}$ & $71.8 \mathrm{~b}$ & $73.8 \mathrm{AB}$ & $70.3 \mathrm{~B}$ & $77.8 \mathrm{~A}$ & $72.2 \mathrm{AB}$ \\
\hline Flesh thickness $(\mathrm{cm})$ & $1.77 \mathrm{a}$ & $1.73 \mathrm{a}$ & $1.65 \mathrm{~b}$ & $1.73 \mathrm{~A}$ & $1.74 \mathrm{~A}$ & $1.70 \mathrm{~A}$ & $1.70 \mathrm{~A}$ \\
\hline Flesh weight $(\mathrm{g})$ & $74.1 \mathrm{a}$ & $64.5 \mathrm{~b}$ & $65.1 \mathrm{~b}$ & $68.0 \mathrm{~B}$ & $65.7 \mathrm{C}$ & $71.1 \mathrm{~A}$ & $66.7 \mathrm{BC}$ \\
\hline \multicolumn{8}{|c|}{ Leaves measures: } \\
\hline Leaf area $(\mathrm{cm} 2)$ & $37.69 \mathrm{a}$ & $37.29 \mathrm{a}$ & $35.78 \mathrm{~b}$ & $34.83 \mathrm{D}$ & $39.31 \mathrm{~A}$ & $35.85 \mathrm{C}$ & $37.69 \mathrm{~B}$ \\
\hline Chlorophyll content $(\%)$ & $39.70 \mathrm{a}$ & $39.48 \mathrm{a}$ & $38.36 \mathrm{~b}$ & $36.89 \mathrm{C}$ & $41.25 \mathrm{~A}$ & $39.11 \mathrm{~B}$ & $39.47 \mathrm{~B}$ \\
\hline Nitrogen leaf content, N (\%) & $2.519 \mathrm{~b}$ & $2.721 \mathrm{a}$ & $2.556 \mathrm{~b}$ & $2.418 \mathrm{C}$ & $2.807 \mathrm{~A}$ & $2.588 \mathrm{~B}$ & $2.580 \mathrm{~B}$ \\
\hline Phosphorus leaf content, $\mathrm{P}(\%)$ & $0.173 \mathrm{c}$ & $0.211 \mathrm{a}$ & $0.186 \mathrm{~b}$ & $0.106 \mathrm{C}$ & $0.257 \mathrm{~A}$ & $0.194 \mathrm{~B}$ & $0.204 \mathrm{~B}$ \\
\hline Potassium leaf content, K (\%) & $1.173 \mathrm{~b}$ & $1.222 \mathrm{a}$ & $1.183 \mathrm{~b}$ & $1.120 \mathrm{D}$ & $1.238 \mathrm{~A}$ & $1.197 \mathrm{C}$ & $1.216 \mathrm{~B}$ \\
\hline \multicolumn{8}{|c|}{ Juice measures: } \\
\hline TSS $(\%)$ & $12.97 \mathrm{a}$ & $12.64 \mathrm{ab}$ & $12.31 \mathrm{~b}$ & $12.29 \mathrm{BC}$ & $11.58 \mathrm{C}$ & $13.09 \mathrm{AB}$ & $13.60 \mathrm{~A}$ \\
\hline Total acidity, TA $(\%)$ & $0.87 \mathrm{~b}$ & $0.90 \mathrm{~b}$ & $0.95 \mathrm{a}$ & $0.99 \mathrm{~A}$ & $0.78 \mathrm{C}$ & $0.93 \mathrm{~B}$ & $0.92 \mathrm{~B}$ \\
\hline Maturity index, MI (-) & $14.90 \mathrm{a}$ & $14.13 \mathrm{a}$ & $13.13 \mathrm{~b}$ & $12.59 \mathrm{~B}$ & $14.86 \mathrm{~A}$ & $14.05 \mathrm{~A}$ & $14.71 \mathrm{~A}$ \\
\hline Total sugars, TSG (g/100cc) & $4.09 \mathrm{~b}$ & $4.64 \mathrm{a}$ & $4.12 \mathrm{~b}$ & $4.04 \mathrm{~B}$ & $4.84 \mathrm{~A}$ & $4.10 \mathrm{~B}$ & $4.16 \mathrm{~B}$ \\
\hline
\end{tabular}

D4, D2, D0: deficiency percent, subscripts refer to $40 \%, 20 \%$, and $0 \%$ deficiency, GC: $4 \mathrm{~L} / \mathrm{h}$ ground drip irrigation, SC: 4L/h subsurface drip irrigation, GL: ground drip irrigation with low flow emitter, SL: subsurface drip with low flow emitter, LSD: least significant difference at $\mathrm{p}=0.05$.

* Means with the same letter for each row, and same group are not significantly different from each other at 0.05 level. Capital letters are used for Irrigation profiles comparisons, while small letters are used for deficiency levels comparisons. 


\section{Leaves measures}

The surface area of the leaves also affected by the DL $\times$ IR interaction, as the largest area occurred at the GL-D2 followed by the SL-D0 in the first year, Table 5, while the largest area in the second year occurred at the GL-D0,2 treatments. The table showed that the low flow treatments (GL-D* and SL-D*, the asterisk means for any deficiency level) result in larger leaf area in the two years.

The chemical analysis showed that the highest chlorophyll content occurred at GL-D* (7-12\% higher than the control), while the lowest values were achieved at the GC-D*. Similarly, the treatments GL-D* showed dominance on the $\mathrm{N}, \mathrm{P}$, and $\mathrm{K}$ contents as listed in Table 5.

\section{Juice measures}

The interaction DL $\times$ IR was not significant in most of the juice measures as shown in Table 3. The TSS and TA values showed a direct proportion to DL in the first year, Table 4, as the TSS increased with the increase of deficiency. The TSS relationship was not significant in the second year.

Consequently, the maturity index (MI) showed different trends in the first and second years; while relationship is not significant in the first year, it showed significance in the second year with $8-14 \%$ less MI when applying the D2 and D4 respectively, Table 4 . The IR treatments showed significant effect on the MI as well; the least MI obtained from the GC treatment in the two years, while there were no significant differences between any of the other three irrigation profiles with $12-23 \%$ more MI values, Table 4.

The maximum resulted total sugars (TSG) were in the GL-D2 treatment in the first year, $13 \%$ more than the control, while the maximum TSG for the second year was obtained at the D2 level of deficiency, $4.6 \mathrm{~g} / 100 \mathrm{c}$, which is about $13 \%$ more than the D0 and D4 levels. Still, the irrigation profile analysis showed that the GL profile gave the maximum TSG by about $20 \%$ more than the conventional treatment GC.

\section{Water and salts distribution in soil}

To have a better understanding of the trees reaction to the irrigation scheme we measured the soil water and salts distribution under the orchards at different times. Due to the large number of treatment-combinations and to make it easy to interpret the results, we have combined the water and salts maps into one map per treatment. The maps were stacked so that each water map is in the bottom and the salts map is overlaying it with 40\% transparency, Figure 2. 


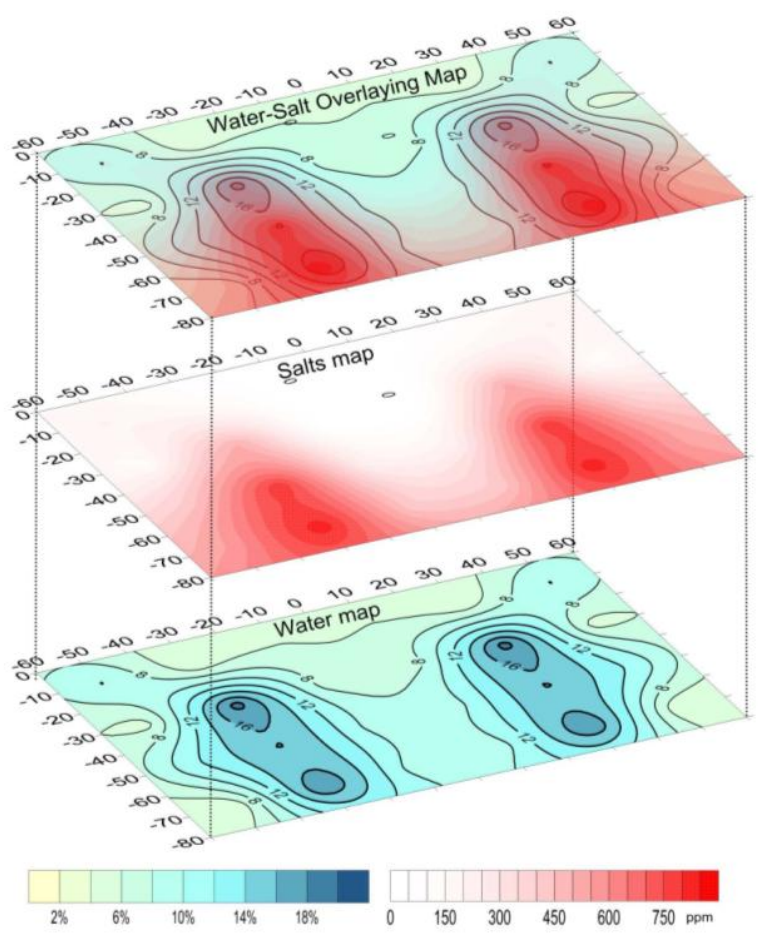

Figure 2. The overlayed maps of salt and water forming a combined map *: water map units are soil-water content (\% by volume), salts map values are TSS (ppm).

The combined maps are shown in Figures 3 and 4 for surface and subsurface treatments respectively. In this paper, we publish only the results of the second year late season measures in for the D0 treatment, the results of the other timings and deficiency levels will be published in a separate paper.

For the ground drip treatments, Figure 3, the conventional drip flow rate appears to flush salts more efficiently than the low flow drip does. It is noticed that the salts appear after irrigation, Figure $3 \mathrm{a}, \mathrm{b}$, but the higher flow emitter, a, seems to flush water from the upper $20 \mathrm{~cm}$, while the lower flow rate, $\mathrm{b}$, can hardly flush some salts just around the emitter. The salt flushing process continues with water redistribution, Figure $3 \mathrm{c}-\mathrm{f}$, with faster rate at the conventional drip (c, e), and slower at the low flow drip treatments $(d, f)$. At the same token the subsurface treatments act, Figure 4, the conventional treatments showed less salt accumulation than the low-flow treatments. Furthermore, the subsurface treatments, in general, showed less salt accumulation than the ground treatments. 
Table 5. Means of the interaction between irrigation profiles and deficiency levels on the studied properties

\begin{tabular}{|c|c|c|c|c|c|c|c|c|c|c|c|c|}
\hline Year 1 & GC-D 0 & GC-D 2 & GC-D 4 & GL-D 0 & GL-D 2 & GL-D 4 & $\mathrm{SC}-\mathrm{D}_{0}$ & $\mathrm{SC}-\mathrm{D}_{2}$ & $\mathrm{SC}-\mathrm{D}_{4}$ & SL-D 0 & SL-D 2 & SL-D 4 \\
\hline Yield (kg/tree) & $21.5 \mathrm{~b}-\mathrm{d}$ & $20.7 \mathrm{c}-\mathrm{e}$ & $17.3 \mathrm{e}$ & $25.1 \mathrm{ab}$ & $25.3 \mathrm{a}$ & $24.5 \mathrm{ab}$ & $20.2 \mathrm{de}$ & $22.1 \mathrm{a}-\mathrm{d}$ & $18.9 \mathrm{de}$ & $24.1 \mathrm{a}-\mathrm{c}$ & $22.4 \mathrm{a}-\mathrm{d}$ & 20.3 \\
\hline $\begin{array}{c}\text { Water use efficiency } \\
(\mathrm{kg} / \mathrm{m} 3)\end{array}$ & $1.91 \mathrm{f}$ & $2.36 \mathrm{de}$ & $2.56 \mathrm{~cd}$ & 2.13 ef & $2.77 \mathrm{bc}$ & $3.39 \mathrm{a}$ & $1.93 \mathrm{f}$ & 2.20 ef & $2.67 \mathrm{~b}-\mathrm{d}$ & $2.15 \mathrm{ef}$ & $2.42 \mathrm{de}$ & $3.01 \mathrm{~b}$ \\
\hline Fruit weight $(\mathrm{g})$ & $72.2 \mathrm{a}$ & $69.0 \mathrm{a}-\mathrm{c}$ & $63.4 \mathrm{c}-\mathrm{e}$ & $71.5 \mathrm{ab}$ & $64.8 \mathrm{c}-\mathrm{e}$ & $65.8 \mathrm{~b}-\mathrm{e}$ & $68.1 \mathrm{a}-\mathrm{d}$ & $61.9 \mathrm{e}$ & $62.9 \mathrm{de}$ & $68.9 \mathrm{a}-\mathrm{d}$ & $64.6 \mathrm{c}-\mathrm{e}$ & $68.6 \mathrm{a}$ \\
\hline Fruit height $(\mathrm{cm})$ & $4.91 \mathrm{ab}$ & $4.85 \mathrm{a}-\mathrm{c}$ & $4.64 \mathrm{bc}$ & $4.65 \mathrm{bc}$ & $4.75 \mathrm{a}-\mathrm{c}$ & $4.66 \mathrm{bc}$ & $4.89 \mathrm{a}-\mathrm{c}$ & $4.78 \mathrm{a}-\mathrm{c}$ & $4.61 \mathrm{c}$ & $4.79 \mathrm{a}-\mathrm{c}$ & $4.87 \mathrm{a}-\mathrm{c}$ & 4.98 \\
\hline Fruit diameter $(\mathrm{cm})$ & $5.28 \mathrm{a}$ & $5.10 \mathrm{a}-\mathrm{c}$ & $4.61 \mathrm{e}$ & $5.20 \mathrm{a}$ & $4.96 \mathrm{~b}-\mathrm{d}$ & $4.89 \mathrm{~cd}$ & $5.10 \mathrm{a}-\mathrm{c}$ & $4.87 \mathrm{~d}$ & $4.85 \mathrm{~d}$ & $5.12 \mathrm{ab}$ & $5.10 \mathrm{a}-\mathrm{c}$ & 4.92 \\
\hline Fruit volume $(\mathrm{cm} 3)$ & $53.6 \mathrm{a}-\mathrm{c}$ & $60.8 \mathrm{a}$ & $57.8 \mathrm{ab}$ & $57.7 \mathrm{ab}$ & $55.3 \mathrm{ab}$ & $56.0 \mathrm{ab}$ & $41.2 \mathrm{e}$ & $44.8 \mathrm{de}$ & $45.9 \mathrm{c}-\mathrm{e}$ & $56.7 \mathrm{ab}$ & $56.3 \mathrm{ab}$ & 52.1 \\
\hline Flesh thickness $(\mathrm{cm})$ & $1.58 \mathrm{ab}$ & $1.55 \mathrm{a}-\mathrm{c}$ & $1.43 \mathrm{~cd}$ & $1.64 \mathrm{a}$ & $1.54 \mathrm{a}-\mathrm{c}$ & $1.47 \mathrm{~b}-\mathrm{d}$ & $1.52 \mathrm{a}-\mathrm{d}$ & $1.51 \mathrm{a}-\mathrm{d}$ & $1.41 \mathrm{~d}$ & $1.48 \mathrm{~b}-\mathrm{d}$ & $1.59 \mathrm{ab}$ & $1.50 \mathrm{~b}$ \\
\hline Flesh weight (g) & $64.2 \mathrm{a}$ & $60.9 \mathrm{a}-\mathrm{c}$ & $55.3 \mathrm{~cd}$ & $63.4 \mathrm{ab}$ & $56.6 \mathrm{~cd}$ & $57.6 \mathrm{~b}-\mathrm{d}$ & $60.2 \mathrm{a}-\mathrm{c}$ & $53.8 \mathrm{~d}$ & $54.9 \mathrm{~cd}$ & $60.9 \mathrm{a}-\mathrm{c}$ & $56.4 \mathrm{~cd}$ & $60.5 \mathrm{a}$ \\
\hline Leaf area $\left(\mathrm{cm}^{2}\right)$ & $34.34 \mathrm{ef}$ & $33.54 \mathrm{f}$ & $32.06 \mathrm{~g}$ & $36.2 \mathrm{~b}-\mathrm{d}$ & $37.92 \mathrm{a}$ & $37.0 \mathrm{a}-\mathrm{c}$ & $35.87 \mathrm{~cd}$ & $34.96 \mathrm{de}$ & $33.93 \mathrm{ef}$ & $37.3 \mathrm{ab}$ & $36.9 \mathrm{a}-\mathrm{c}$ & 35.68 \\
\hline $\begin{array}{c}\text { Chlorophyll content } \\
(\%)\end{array}$ & $34.9 \mathrm{de}$ & 34.1 ef & $33.1 \mathrm{f}$ & $37.8 \mathrm{a}$ & $37.3 \mathrm{ab}$ & $36.1 \mathrm{bc}$ & $35.3 \mathrm{~cd}$ & $35.4 \mathrm{~cd}$ & $35.1 \mathrm{c}-\mathrm{e}$ & $35.7 \mathrm{~cd}$ & $35.9 \mathrm{~cd}$ & $35.0 \mathrm{c}$ \\
\hline $\begin{array}{c}\text { Nitrogen leaf } \\
\text { content, N }(\%)\end{array}$ & $2.448 \mathrm{~d}$ & $2.457 \mathrm{~d}$ & $2.512 \mathrm{~d}$ & $2.497 \mathrm{~d}$ & $2.935 \mathrm{a}$ & $2.837 \mathrm{ab}$ & $2.452 \mathrm{~d}$ & $2.687 \mathrm{bc}$ & $2.602 \mathrm{~cd}$ & $2.529 \mathrm{~cd}$ & $2.815 \mathrm{ab}$ & $2.486 \mathrm{~d}$ \\
\hline $\begin{array}{l}\text { Phosphorus leaf } \\
\text { cont., } \mathrm{P}(\%)\end{array}$ & $0.103 \mathrm{~g}$ & $0.126 \mathrm{f}$ & $0.104 \mathrm{~g}$ & $0.208 \mathrm{c}$ & $0.272 \mathrm{a}$ & $0.235 \mathrm{~b}$ & $0.185 \mathrm{~d}$ & $0.205 \mathrm{~cd}$ & $0.187 \mathrm{~cd}$ & $0.157 \mathrm{e}$ & $0.199 \mathrm{~cd}$ & $0.205 \mathrm{~cd}$ \\
\hline $\begin{array}{c}\text { Potassium leaf cont., } \\
\mathrm{K}(\%) \\
\end{array}$ & $1.101 \mathrm{e}$ & $1.125 \mathrm{e}$ & $1.101 \mathrm{e}$ & $1.168 \mathrm{~d}$ & $1.269 \mathrm{a}$ & $1.215 \mathrm{~b}$ & $1.159 \mathrm{~d}$ & $1.185 \mathrm{~cd}$ & $1.167 \mathrm{~d}$ & $1.209 \mathrm{bc}$ & $1.230 \mathrm{~b}$ & $1.183 \mathrm{~cd}$ \\
\hline TSS (\%) & $11.14 \mathrm{a}$ & $12.10 \mathrm{a}$ & $12.13 \mathrm{a}$ & $9.67 \mathrm{~b}$ & $11.34 \mathrm{a}$ & $11.99 \mathrm{a}$ & $11.07 \mathrm{ab}$ & $11.91 \mathrm{a}$ & $11.60 \mathrm{a}$ & $10.8 \mathrm{ab}$ & $11.48 \mathrm{a}$ & \\
\hline $\begin{array}{c}\text { Total acidity, TA } \\
(\%)\end{array}$ & $0.926 \mathrm{bc}$ & $1.037 \mathrm{a}$ & $0.988 \mathrm{ab}$ & $0.704 \mathrm{e}$ & $0.75 \mathrm{de}$ & $0.776 \mathrm{de}$ & $0.775 \mathrm{de}$ & $0.809 \mathrm{~d}$ & $0.831 \mathrm{~cd}$ & $0.700 \mathrm{e}$ & $0.777 \mathrm{de}$ & $0.808 \mathrm{~d}$ \\
\hline $\begin{array}{c}\text { Maturity index, MI (- } \\
\text { ) }\end{array}$ & $12.0 \mathrm{~cd}$ & $11.9 \mathrm{~d}$ & $12.3 \mathrm{~b}-\mathrm{d}$ & $13.8 \mathrm{a}-\mathrm{d}$ & $15.1 \mathrm{a}$ & $15.4 \mathrm{a}$ & $14.3 \mathrm{a}-\mathrm{c}$ & $14.7 \mathrm{a}$ & $14.0 \mathrm{a}-\mathrm{d}$ & $15.5 \mathrm{a}$ & $14.8 \mathrm{a}$ & $14.4 \mathrm{ab}$ \\
\hline $\begin{array}{c}\text { Total sugars, TSG } \\
(\mathrm{g} / 100 \mathrm{cc})\end{array}$ & $3.98 \mathrm{~b}-\mathrm{e}$ & $4.03 \mathrm{a}-\mathrm{d}$ & $3.45 \mathrm{e}$ & $4.50 \mathrm{ab}$ & $4.51 \mathrm{a}$ & $4.45 \mathrm{a}-\mathrm{c}$ & $3.67 \mathrm{de}$ & $4.11 \mathrm{a}-\mathrm{d}$ & $3.82 \mathrm{de}$ & $3.97 \mathrm{c}-\mathrm{e}$ & $4.07 \mathrm{a}-\mathrm{d}$ & $3.94 \mathrm{c}-\mathrm{e}$ \\
\hline Year 2 & GC-D $D_{0}$ & GC-D $\mathrm{D}_{2}$ & GC-D 4 & GL-D 0 & GL-D 2 & GL-D 4 & $\mathrm{SC}-\mathrm{D}_{0}$ & $\mathrm{SC}-\mathrm{D}_{2}$ & $\mathrm{SC}-\mathrm{D}_{4}$ & SL-D 0 & SL-D 2 & SL-D 4 \\
\hline Yield (kg/tree) & $22.2 \mathrm{a}-\mathrm{c}$ & $20.8 \mathrm{a}-\mathrm{c}$ & $19.9 \mathrm{bc}$ & $21.3 \mathrm{a}-\mathrm{c}$ & $21.3 \mathrm{a}-\mathrm{c}$ & $20.2 \mathrm{bc}$ & $22.3 \mathrm{a}-\mathrm{c}$ & $22.1 \mathrm{a}-\mathrm{c}$ & $20.0 \mathrm{bc}$ & $24.0 \mathrm{a}$ & $23.4 \mathrm{ab}$ & $18.9 \mathrm{c}$ \\
\hline $\begin{array}{c}\text { Water use efficiency } \\
(\mathrm{kg} / \mathrm{m} 3)\end{array}$ & $1.85 \mathrm{f}$ & $2.26 \mathrm{~d}-\mathrm{f}$ & $2.80 \mathrm{a}-\mathrm{c}$ & $1.86 \mathrm{f}$ & $2.22 \mathrm{~d}-\mathrm{f}$ & $2.96 \mathrm{ab}$ & $1.93 \mathrm{ef}$ & $2.37 \mathrm{c}-\mathrm{e}$ & $2.90 \mathrm{ab}$ & $2.08 \mathrm{~d}-\mathrm{f}$ & $2.47 \mathrm{~b}-\mathrm{d}$ & $3.01 \mathrm{a}$ \\
\hline Fruit weight $(\mathrm{g})$ & $85.8 \mathrm{a}$ & $75.4 \mathrm{c}$ & $67.0 \mathrm{f}$ & $79.2 \mathrm{~b}$ & $70.2 \mathrm{ef}$ & $71.6 \mathrm{de}$ & $89.0 \mathrm{a}$ & $74.6 \mathrm{~cd}$ & $74.1 \mathrm{~cd}$ & $74.7 \mathrm{~cd}$ & 70.3 ef & $79.8 \mathrm{~b}$ \\
\hline Fruit height $(\mathrm{cm})$ & $5.37 \mathrm{bc}$ & $5.17 \mathrm{c}-\mathrm{e}$ & $4.97 \mathrm{e}$ & $4.98 \mathrm{e}$ & $5.18 \mathrm{c}-\mathrm{e}$ & $5.08 \mathrm{de}$ & $5.64 \mathrm{a}$ & $5.26 \mathrm{~cd}$ & $5.16 \mathrm{c}-\mathrm{e}$ & $5.15 \mathrm{c}-\mathrm{e}$ & $5.34 \mathrm{c}$ & $5.58 \mathrm{ab}$ \\
\hline Fruit diameter $(\mathrm{cm})$ & $5.58 \mathrm{a}$ & $5.27 \mathrm{~b}$ & $4.82 \mathrm{c}$ & $5.38 \mathrm{ab}$ & $5.16 \mathrm{~b}$ & $5.28 \mathrm{~b}$ & $5.63 \mathrm{a}$ & $5.14 \mathrm{~b}$ & $5.13 \mathrm{~b}$ & $5.26 \mathrm{~b}$ & $5.29 \mathrm{~b}$ & $5.20 \mathrm{~b}$ \\
\hline Fruit volume $(\mathrm{cm} 3)$ & $82.8 \mathrm{ab}$ & $74.2 \mathrm{~b}-\mathrm{d}$ & $64.4 \mathrm{de}$ & $77.5 \mathrm{bc}$ & $59.2 \mathrm{e}$ & $74.1 \mathrm{~b}-\mathrm{d}$ & $93.1 \mathrm{a}$ & $68.6 \mathrm{c}-\mathrm{e}$ & $71.7 \mathrm{~b}-\mathrm{e}$ & $73.4 \mathrm{~b}-\mathrm{d}$ & $66.1 \mathrm{c}-\mathrm{e}$ & $77.0 \mathrm{~b}-\mathrm{d}$ \\
\hline Flesh thickness $(\mathrm{cm})$ & $1.81 \mathrm{a}$ & $1.75 \mathrm{ab}$ & $1.62 \mathrm{~d}$ & $1.76 \mathrm{ab}$ & $1.77 \mathrm{ab}$ & $1.70 \mathrm{~b}-\mathrm{d}$ & $1.80 \mathrm{a}$ & $1.68 \mathrm{~b}-\mathrm{d}$ & $1.63 \mathrm{~cd}$ & $1.68 \mathrm{~b}-\mathrm{d}$ & $1.74 \mathrm{a}-\mathrm{c}$ & $1.67 \mathrm{~b}-\mathrm{d}$ \\
\hline Flesh weight (g) & $77.7 \mathrm{a}$ & $67.3 \mathrm{c}$ & $59.1 \mathrm{f}$ & $71.3 \mathrm{~b}$ & $62.2 \mathrm{ef}$ & $63.6 \mathrm{de}$ & $81.0 \mathrm{a}$ & $66.3 \mathrm{~cd}$ & $66.0 \mathrm{~cd}$ & $66.4 \mathrm{~cd}$ & $62.0 \mathrm{ef}$ & $71.7 \mathrm{~b}$ \\
\hline Leaf area $\left(\mathrm{cm}^{2}\right)$ & $35.81 \mathrm{ef}$ & $35.24 \mathrm{fg}$ & $33.43 \mathrm{~h}$ & $40.35 \mathrm{a}$ & $39.48 \mathrm{a}$ & $38.09 \mathrm{~b}$ & $36.7 \mathrm{c}-\mathrm{e}$ & $36.4 \mathrm{~d}-\mathrm{f}$ & $34.45 \mathrm{gh}$ & $37.91 \mathrm{bc}$ & $38.02 \mathrm{~b}$ & $37.1 \mathrm{~b}-\mathrm{d}$ \\
\hline $\begin{array}{c}\text { Chlorophyll content } \\
(\%)\end{array}$ & $37.3 \mathrm{e}$ & $37.2 \mathrm{e}$ & $36.2 \mathrm{f}$ & $41.6 \mathrm{a}$ & $41.4 \mathrm{a}$ & $40.8 \mathrm{ab}$ & $39.8 \mathrm{c}$ & $39.4 \mathrm{c}$ & $38.1 \mathrm{de}$ & $40.1 \mathrm{bc}$ & $39.8 \mathrm{c}$ & $38.5 \mathrm{~d}$ \\
\hline $\begin{array}{r}\text { Nitroge } \\
\text { content, }\end{array}$ & $2.456 \mathrm{e}$ & $2.403 \mathrm{e}$ & $2.396 \mathrm{e}$ & $2.613 \mathrm{~cd}$ & $2.937 \mathrm{a}$ & $2.871 \mathrm{a}$ & $2.520 \mathrm{de}$ & $2.733 \mathrm{bc}$ & $2.509 \mathrm{de}$ & $2.485 \mathrm{de}$ & $2.811 \mathrm{ab}$ & $2.446 \mathrm{e}$ \\
\hline $\begin{array}{c}\begin{array}{c}\text { Phosphorus leaf } \\
\text { cont., } \mathrm{P}(\%)\end{array} \\
\end{array}$ & $0.102 \mathrm{~g}$ & $0.114 \mathrm{~g}$ & $0.103 \mathrm{~g}$ & $0.228 \mathrm{c}$ & $0.290 \mathrm{a}$ & $0.251 \mathrm{~b}$ & $0.173 \mathrm{f}$ & $0.212 \mathrm{~cd}$ & $0.196 \mathrm{de}$ & 0.188 ef & $0.229 \mathrm{bc}$ & $0.194 \mathrm{~d}-\mathrm{f}$ \\
\hline $\begin{array}{c}\text { Potassium leaf cont., } \\
\mathrm{K}(\%)\end{array}$ & $1.133 \mathrm{e}$ & $1.123 \mathrm{ef}$ & $1.104 \mathrm{f}$ & $1.188 \mathrm{~cd}$ & $1.291 \mathrm{a}$ & $1.234 \mathrm{~b}$ & $1.179 \mathrm{~d}$ & $1.234 \mathrm{~b}$ & $1.178 \mathrm{~d}$ & $1.191 \mathrm{~cd}$ & $1.241 \mathrm{~b}$ & $1.216 \mathrm{bc}$ \\
\hline TSS (\%) & $11.9 \mathrm{~b}-\mathrm{d}$ & $12.6 \mathrm{a}-\mathrm{c}$ & $12.4 \mathrm{~b}-\mathrm{d}$ & $12.69 \mathrm{a}-\mathrm{c}$ & $11.39 \mathrm{~cd}$ & $10.65 \mathrm{~d}$ & $13.0 \mathrm{a}-\mathrm{c}$ & $13.1 \mathrm{a}-\mathrm{c}$ & $13.1 \mathrm{a}-\mathrm{c}$ & $14.26 \mathrm{a}$ & $13.44 \mathrm{ab}$ & $13.1 \mathrm{a}-\mathrm{c}$ \\
\hline $\begin{array}{c}\text { Total acidity, TA } \\
(\%)\end{array}$ & $0.905 \mathrm{~b}$ & $0.941 \mathrm{~b}$ & $1.122 \mathrm{a}$ & $0.778 \mathrm{c}$ & $0.770 \mathrm{c}$ & $0.792 \mathrm{c}$ & $0.890 \mathrm{~b}$ & $0.959 \mathrm{~b}$ & $0.948 \mathrm{~b}$ & $0.920 \mathrm{~b}$ & $0.923 \mathrm{~b}$ & $0.931 \mathrm{~b}$ \\
\hline $\begin{array}{c}\text { Maturity index, MI (- } \\
\text { ) }\end{array}$ & $13.2 \mathrm{~cd}$ & $13.5 \mathrm{bc}$ & $11.1 \mathrm{~d}$ & $16.3 \mathrm{a}$ & $14.8 \mathrm{a}-\mathrm{c}$ & $13.4 \mathrm{bc}$ & $14.6 \mathrm{a}-\mathrm{c}$ & $13.7 \mathrm{bc}$ & $13.9 \mathrm{bc}$ & $15.5 \mathrm{ab}$ & $14.6 \mathrm{a}-\mathrm{c}$ & $14.1 \mathrm{bc}$ \\
\hline $\begin{array}{l}\text { Total sugars, TSG } \\
(\mathrm{g} / 100 \mathrm{cc})\end{array}$ & $3.78 \mathrm{~d}$ & $4.48 \mathrm{~b}$ & $3.85 \mathrm{~d}$ & $4.54 \mathrm{~b}$ & $5.18 \mathrm{a}$ & $4.80 \mathrm{ab}$ & $4.00 \mathrm{~d}$ & $4.43 \mathrm{bc}$ & $3.88 \mathrm{~d}$ & $4.05 \mathrm{~cd}$ & $4.47 \mathrm{~b}$ & $3.96 \mathrm{~d}$ \\
\hline
\end{tabular}

LSD: Least significant difference at $\mathrm{p}=0.05$, D4, D2, D0: deficiency percent, subscripts refer to $40 \%$, $20 \%$, and $0 \%$ deficiency, GC: 4L/h ground drip irrigation, SC: $4 \mathrm{~L} / \mathrm{h}$ subsurface drip irrigation, GL: ground drip irrigation with low flow emitter, SL: subsurface drip with low flow emitter.

* Means with the same letter for each row are not significantly different from each other at 0.05 level. 


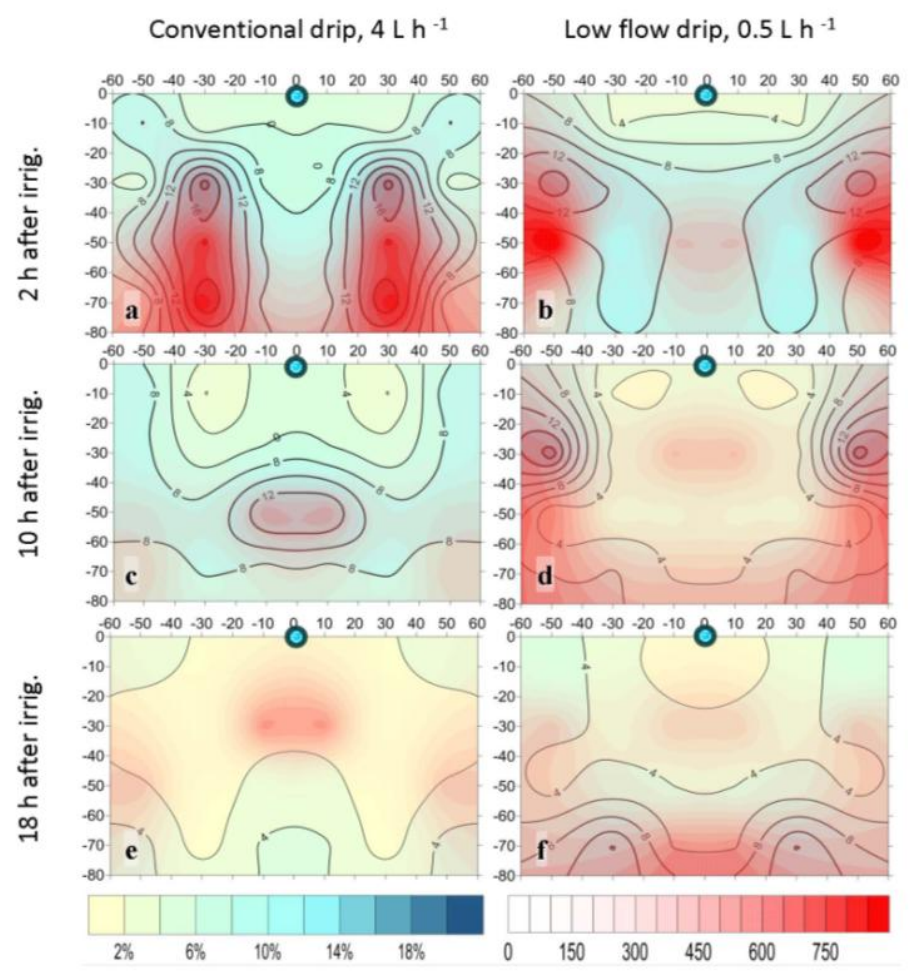

Figure 3. The combined salt and water maps of the conventional and low-flow ground drip irrigation after irrigation in the late season of the second year.

*: water map units are soil-water content (\% by volume), salts map values are TSS (ppm).

For water flow, we noticed that for the ground drip, Figure 3, the lateral movement of the low flow emitters was higher than that of the conventional emitters, as noticed by comparing the location of the higher-flow zones (12\% water content for example) in b vs. a and d vs. c. In comparison, this is not clear for the subsurface drip, Figure 4, but it is observed for subsurface patterns that water intensity below the emitter is higher for low flow patterns. The water pattern figures show an unfamiliar phenomenon, that the surface layer of the ground drip is dryer than the subsurface drip.

Comparing all the salt distribution profiles, we found that the least saltaccumulation occurs at the SC treatment followed by the SL then the GC and finally the GL treatment. All the shown patterns of salts are for D0 treatment, however, salt accumulation problem is worse for the deficit irrigation treatments D2 and D4, data not shown, however, this evidence is supported by the findings of Aragüés et al., (2015). 
Conventional drip, $4 \mathrm{~L} \mathrm{~h}^{-1}$
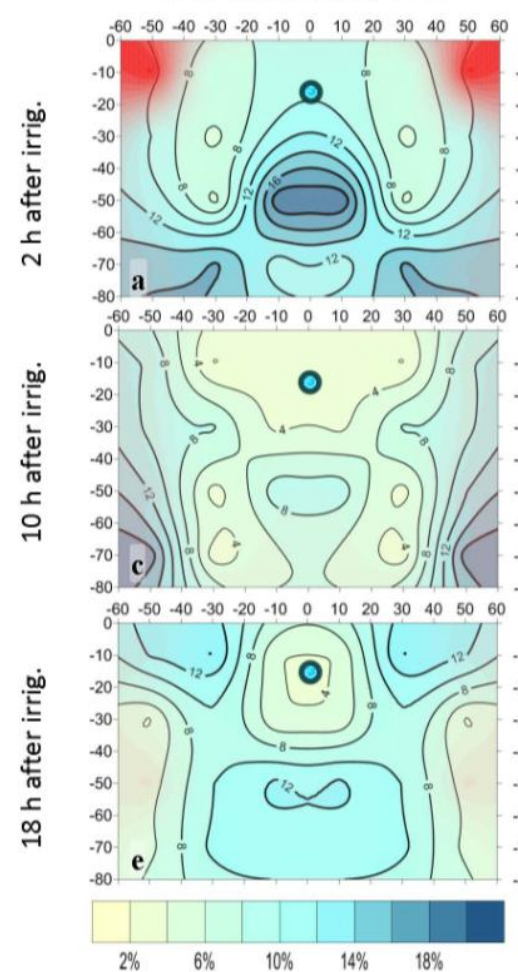

Low flow drip, $0.5 \mathrm{~L} \mathrm{~h}^{-1}$
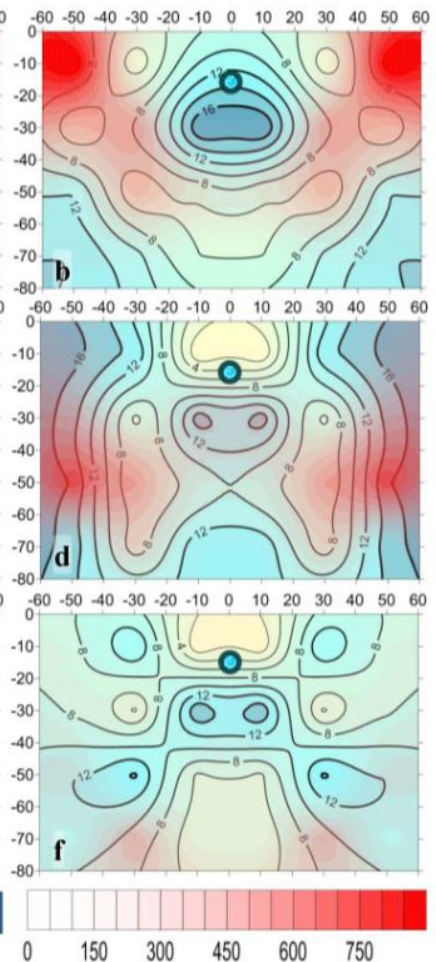

*: water map units are soil-water content (\% by volume), salts map values are TSS (ppm).

Figure 4. The combined salt and water maps of the conventional and low-flow subsurface drip irrigation after irrigation for the second year.

\section{Comparing ground drip to subsurface drip}

As we saw in the second year's results, the irrigation profile had no impact on any of the yield measures. This agrees with other investigators (Aragiés et al., 2014; Bryla et al., 2005), where the formers reported that the two drip profiles produced more yield and bigger peaches than furrow and micro sprinkled systems, but that no differences between ground drip (GD) and subsurface drip (SDI) were found. Correspondingly, some studies reported an increase of pears yield due to the GD system than the SDI, (Oron et al., 2002), and others reported a contrary result that they found that SDI produces more yield than GD (Oron et al., 1999). The main factor that led to this contradiction was water salinity, as SDI gave better results when used with saline water (Oron et al., 1999), while GD gave better results when using fresh water (Oron et al., 2002). In this study, we used a moderate salinity water, Table 1 , as classified by irrigation indices (Ayers and Westcot, 1985; Nakayama and Bucks, 1991), this may attribute our results that no differences between GD and SDI. However, there may be other 
reasons to get the results of SDI and GD to be almost similar, like rain which flushes-out salts (Aloni et al., 2000).

\section{The effect of emitters' flowrate}

The dripping rate whether it is conventional or low flow also did not affect the yield neither the fruit size, this agrees with the results of Worthington and Lasswell, (1994). On the other hand, we found that the irrigation profile has a significant effect in the first year; as the yield for GL treatment is the highest, Table 4, then SL followed by SC and GC. This shows that the low flow emitters (L) gave better results than the conventional emitters (C) did, but in the existence of the L emitters, the ground installation is better than the subsurface installation, while with the $\mathrm{C}$ emitters, the subsurface installation is better than the ground installation. This may be attributed to some root damage at the depth of subsurface laterals while installation, hence, when we apply low flow emitters to the SDI, water spread around the lateral in the damaged-roots region leading to less benefit of water and nutrients, and hence less yield. On the other hand, when the conventional flow is applied through SDI, water flows deeper by the effect of flux that allows the plant to benefit from extra amount of water. Conversely, on the ground drip treatments, there were no damaged-roots problem, and the roots in the top layer were active and effective to capture each drop of the low flow application that limits the evaporation and runoff losses as opposed to the conventional flow. In this study, the problem of damaged-roots occurred only at the first year of the experiment as reported by also by Burt, (1996). Although the second year's results showed no significance of the irrigation system on the yield quantity, Table 4, but the fruit quality is highly affected by the irrigation profile in the two years, especially the maturity index (MI) and total sugars (TSG). In the two years, the results of the low flow treatments were higher in MI and in TSG, Table 4. The highest MI was achieved at the GL irrigation; however, the values are not statistically different from SL and SC treatments while differs significantly from the control, GC, treatment that gives the lowest values. In addition to the high TSG values as a marketing advantage, the high MI value leads to early marketing, which in turn leads to the advantage of higher selling prices.

\section{The effect of deficiency level}

Unlike the D4 deficiency level, the D2 levels did not led to any significant reduction in yield in both years, Table 4, while the WUE is significantly higher in for $\mathrm{D}_{2}$ than $\mathrm{D} 0$. This leads us to recommend using $\mathrm{D}_{2}$ for its benefits gaining about $20 \%$ more WUE with negligible reduction in yield. This agrees with Gunduz et al., (2011) when irrigating every 6 days. Although the $\mathrm{D}_{4}$ treatment led to $43,50 \%$ increase in the WUE in the two years respectively, agreeing with Verma et al., (2007) and Tejero et al., (2011), it caused 12, 14\% yield reduction. If this quantity matters and the water is not scarce, then the $\mathrm{D}_{4}$ level should not be used (Aragüés et al., 2014; Mounzer et al., 2013; Tejero et al., 2011; Vera et al., 
2013), otherwise, we should recommend using the $\mathrm{D}_{4}$ level of deficiency because of its water conservation benefits.

In addition to the water reduction effect, water deficiency may cause a side effect increasing the soil salinity (Pedrero et al., 2014) which increases the impact on yield. Furthermore, our results showed that the increase in DL result in higher TA values in fruit juice, and in contrast a lower maturity index values which is a good marketing factor as it reflects sweeter and tastier fruits (Shinya et al., 2014), these results agree with Conesa et al., (2014) who performed similar experiments on mandarin. The results of total sugars analysis reinforces the previous results as $D_{2}$ treatment showed up to $13 \%$ more sugars than both the $D_{0}$ and the $\mathrm{D}_{4}$ treatments, this means that $\mathrm{D}_{2}$ treatment produced the sweetest and tastiest fruits than the two other treatments.

\section{Water and salts}

As we said that the drippers with conventional flowrate value appears to flush salts more efficiently than the low flow drip does which can be attributed to the relative flux of the conventional flow dripper to the low flow dripper $\left(4 \mathrm{~L} \mathrm{~h}^{-}\right.$ ${ }^{1}, 0.5 \mathrm{~L} \mathrm{~h}^{-1}$ respectively). Additionally, the less salt accumulation, which occur in the subsurface treatments than the ground drip treatments, may be attributed to the emitter's location. The central location of the subsurface emitter helps pushing salts to the edges of the profile in all directions as reported by others (Lamm and Camp, 2007; Oron et al., 1999), rather than the surface dripper that flushes salts mainly downwards.

The increase in the lateral movement of water for the low flow emitters than the conventional emitters may be attributed to the increase in the matric flux component over the gravimetric component of the soil-water movement forces this happens mainly for low fluxes (Gardner and Hsieh, 1959).

The dryness of thee surface layer of the ground drip than that of the subsurface drip could be attributed to the upward water movement from the shallow-buried emitter, or due to the differences between root patterns and special soil variability as reported elsewhere (Olsson and Rose, 1988; Rolston et al., 1991).

\section{CONCLUSIONS}

In conclusion, we can say that in this study, DL reduces yield only at D4 level, while it increases WUE, and enhances the fruit quality. Furthermore, the low-flow irrigation enhances water lateral movement, and fruit quality, but it has low ability to flush salts from soil. It can be recommended to implement more studies on the low-flow drip application for different soil textures and crops, it is also recommended to apply the $\mathrm{D}_{2}$ deficiency level due to its benefits of improving fruit quality, increasing WUE, and for its low impact on yield reduction. Finally, under economic balanced conditions, it is recommended to apply the low-flow ground drip with $\mathrm{D}_{2}$ level. 


\section{REFERENCES}

Abdou, S.H., Hegazi, M.M., El-Gindy, A.-G.M., Sorlini, C., 2010. Performance of Ultra-Low Rate of Trickle Irrigation. Misr J Ag Eng, Irrigation Engineering 27, 549-564.

Abramowitz, M., Stegun, I.A., 2012. Handbook of Mathematical Functions: with Formulas, Graphs, and Mathematical Tables. Courier Corporation.

Abrisqueta, I., Tapia, L.M., Conejero, W., Sanchez-Toribio, M.I., Abrisqueta, J.M., Vera, J., Ruiz-Sanchez, M.C., 2010. Response of early-peach [Prunus persica (L.)] trees to deficit irrigation. Span. J. Agric. Res. 8, 30-39. doi:10.5424/sjar/201008S2-1345

Allen, R.G., Pereira, L.S., Raes, D., Smith, M., 1998. Crop evapotranspiration Guidelines for computing crop water requirements - FAO Irrigation and drainage paper 56, FAO Irrigation and Drainage Papers. Food and Agriculture Organization of the United Nations, Rome.

Aloni, N.I., Eizencot, A., Steinberg, Y., Levy, U., Yotal, Y., Golan, Z., 2000. Fertigation management and salinity monitoring of cotton cultivated in deep subsurface drip irrigation system, in: Irrig. Assoc. Australia,. Australia, pp. 153-157.

Aragüés, R., Medina, E.T., Martínez-Cob, A., Faci, J., 2014. Effects of deficit irrigation strategies on soil salinization and sodification in a semiarid drip-irrigated peach orchard. Agric. Water Manag. 142, 1-9. doi:10.1016/j.agwat.2014.04.004

Aragüés, R., Medina, E.T., Zribi, W., Clavería, I., Álvaro-Fuentes, J., Faci, J., 2015. Soil salinization as a threat to the sustainability of deficit irrigation under present and expected climate change scenarios. Irrig. Sci. 33, 67-79. doi:10.1007/s00271014-0449-x

Ayers, R.S., Westcot, D.W., 1985. Water Quality for Agriculture, FAO Irrigation and Drainage Paper \# 29 Rev.1. Food and Agriculture Organization of the United Nations, Rome.

Brooks, S.J., Moore, J.N., Murphy, J.B., 1993. Quantitative and Qualitative Changes in Sugar Content of Peach Genotypes [Prunus persica (L.) Batsch.]. J. Am. Soc. Hortic. Sci. 118, 97-100.

Brown, J.O., Lilleland, O., 1966. Rapid determination of potassium and sodium in plant material and soil extracts by Flamephotometery. J. Am. Soc. Hortic. Sci. 48, 344 346.

Bryla, D.R., Dickson, E., Shenk, R., Johnson, R.S., Crisosto, C.H., Trout, T.J., 2005. Influence of Irrigation Method and Scheduling on Patterns of Soil and Tree Water Status and Its Relation to Yield and Fruit Quality in Peach. HortScience 40, 2118-2124.

Bryla, D.R., Trout, T.J., Ayars, J.E., Johnson, R.S., 2003. Growth and Production of Young Peach Trees Irrigated by Furrow, Microjet, Surface Drip, or Subsurface Drip Systems. HortScience 38, 1112-1116.

Burt, C.M., 1996. Buried Drip Irrigation on Pistachios Study (Project summary report No. ITRC Report No. R 96-003), CEC - Munger-Poonian Farms Report. California Polytechnic State University, Irrigation Training and Research Center, California.

Cetin, B., Tipi, T., Ozer, H., Yazgan, S., 2003. Economics of drip irrigation for peach (Prunus persica) orchards in Turkey. N. Z. J. CROP Hortic. Sci. 31, 85-90.

Chapman, H.D., Pratt, P.F., 1961. Methods of Analysis for Soils, Plants and Waters, 1st Edition edition. ed. University of California, Division of Agricultural Sciences.

Conesa, M.R., García-Salinas, M.D., de la Rosa, J.M., Fernández-Trujillo, J.P., Domingo, R., Pérez-Pastor, A., 2014. Effects of deficit irrigation applied during fruit growth period of late mandarin trees on harvest quality, cold storage and 
subsequent shelf-life. Sci. Hortic. $\quad$ 165, 344-351. doi:10.1016/j.scienta.2013.11.023

Cunniff, P.A. (Ed.), 1999. Official Methods of Analysis of Aoac International, 16th edition. ed. Aoac Intl, Arlington, Va.

Doorenbos, J., Pruitt, W.O., 1977. Guidelines for predicting crop water requirements, Rev. ed, FAO irrigation and drainage paper ; 24. Food and Agriculture Organization of the United Nations, Rome.

Faust, M., Timon, B., 1995. Origin and Dissemination of Peach, in: Janick, J. (Ed.), Horticultural Reviews. John Wiley \& Sons, Inc., pp. 331-379.

Gardner, W.H., 1986. Water content, in: Klute, A. (Ed.), Methods of Soil Analysis. Part 1. Physical and Mineralogical Methods, Agronomy. American Society of Agronomy-Soil Science Society of America, Madison, Wis., pp. 493-544.

Gardner, W.H., Hsieh, J.C., 1959. Water movement in soils. Washington State University.

Germaine, J.T., Germaine, A.V., 2009. Geotechnical Laboratory Measurements for Engineers. John Wiley \& Sons.

Gilead, G., 2002. Ultra-Low Drip Irrigation. Trickle- Forum, http://www.trickle1.com/new/archives/uldi.html Accessed 26/11/2014.

Goldhamer, D.A., Salinas, M., Anaya, M.S., Elvira, A.M., 2001. Peach trees perform similarly despite different irrigation scheduling methods. Calif. Agric. 1, 25-29.

Gunduz, M., Korkmaz, N., Asik, S., Unal, H.B., Avci, M., 2011. Effects of Various Irrigation Regimes on Soil Water Balance, Yield, and Fruit Quality of DripIrrigated Peach Trees. J. Irrig. Drain. Eng. 137, 426-434. doi:10.1061/(ASCE)IR.1943-4774.0000310

Kader, A.A., 1999. Fruit Maturity, Ripening, and Quality Relationships | International Society for Horticultural Science. Acta Hort, International Symposium Effect of Pre- \&amp; Postharvest factors in Fruit Storage 485, 203-208.

Kang, S.Z., Shi, P., Pan, Y.H., Liang, Z.S., Hu, X.T., Zhang, J., 2000. Soil water distribution, uniformity and water-use efficiency under alternate furrow irrigation in arid areas. Irrig. Sci. 19, 181-190. doi:10.1007/s002710000019

Lamm, F.R., Camp, C.R., 2007. 13. Subsurface drip irrigation, in: Freddie R. Lamm, J.E.A. and F.S.N. (Ed.), Developments in Agricultural Engineering, Microirrigation for Crop Production Design, Operation, and Management. Elsevier, pp. 473-551.

Mead, R., 2001. Minute or Ultra-low microirrigation. Trickle- Forum, http://www.trickle-l.com/new/archives/min_ultra.html. Accessed 26/11/2014.

Mounzer, O., Pedrero-Salcedo, F., Nortes, P.A., Bayona, J.-M., Nicolás-Nicolás, E., Alarcón, J.J., 2013. Transient soil salinity under the combined effect of reclaimed water and regulated deficit drip irrigation of Mandarin trees. Agric. Water Manag., Soil and Irrigation Sustainability Practices 120, 23-29. doi:10.1016/j.agwat.2012.10.014

Nakayama, F.S., Bucks, D.A., 2012. Trickle Irrigation for Crop Production: Design, Operation and Management. Elsevier.

Nakayama, F.S., Bucks, D.A., 1991. Water quality in drip/trickle irrigation: A review. Irrig. Sci. 12, 187-192. doi:10.1007/BF00190522

Olsson, K.A., Rose, C.W., 1988. Patterns of water withdrawal beneath an irrigated peach orchard on a red-brown earth. Irrig. Sci. 9, 89-104. doi:10.1007/BF00262353

Oron, G., DeMalach, Y., Gillerman, L., David, I., Lurie, S., 2002. SW-Soil and Water: Effect of Water Salinity and Irrigation Technology on Yield and Quality of Pears. Biosyst. Eng. 81, 237-247. doi:10.1006/bioe.2001.0038 
Oron, G., DeMalach, Y., Gillerman, L., David, I., Rao, V.P., 1999. Improved salinewater use under subsurface drip irrigation. Agric. Water Manag. 39, 19-33. doi:10.1016/S0378-3774(98)00088-2

Pedrero, F., Maestre-Valero, J.F., Mounzer, O., Alarcón, J.J., Nicolás, E., 2014. Physiological and agronomic mandarin trees performance under saline reclaimed water combined with regulated deficit irrigation. Agric. Water Manag. 146, 228 237. doi:10.1016/j.agwat.2014.08.013

Pliakoni, E.D., Nanos, G.D., 2010. Deficit Irrigation and Reflective Mulch Effects on Peach and Nectarine Fruit Quality and Storage Ability. Acta Hortic., PROCEEDINGS OF THE VITH INTERNATIONAL POSTHARVEST SYMPOSIUM 1, 215-222.

Rahil, M.H., Qanadillo, A., 2015. Effects of different irrigation regimes on yield and water use efficiency of cucumber crop. Agric. Water Manag. 148, 10-15. doi:10.1016/j.agwat.2014.09.005

Rolston, D.E., Biggar, J.W., Nightingale, H.I., 1991. Temporal persistence of spatial soil-water patterns under trickle irrigation. Irrig. Sci. 12, 181-186. doi:10.1007/BF00190521

Rufat, J., Arbonés, A., Villar, P., Domingo, X., Pascual, M., Villar, J.M., 2010. Effects Of Irrigation And Nitrogen Fertilization On Growth, Yield And Fruit Quality Parameters Of Peaches For Processing. Acta Hortic.

Shinya, P., Contador, L., Frett, T., Infante, R., 2014. Effect of prolonged cold storage on the sensory quality of peach and nectarine. Postharvest Biol. Technol. 95, 7-12. doi:10.1016/j.postharvbio.2014.03.001

Sonon, L.S., Saha, U., Kissel, D.E., 2012. Soil Salinity. Testing, Data Interpretation and $\begin{array}{lllll}\text { Recommendations. UGA Coop. } & \text { Ext. Circ. }\end{array}$ http://extension.uga.edu/publications/detail.cfm?number=C1019. Accessed: 16/9/2015.

Steyermark, A. (Ed.), 1961. CHAPTER 8 - Microdetermination of Nitrogen by the Kjeldahl Method, in: Quantitative Organic Microanalysis (Second Edition). Academic Press, pp. 188-220.

Tejero, I.G., Zuazo, V.H.D., Bocanegra, J.A.J., Fernández, J.L.M., 2011. Improved water-use efficiency by deficit-irrigation programmes: Implications for saving water in citrus orchards. Sci. Hortic. 128, 274-282. doi:10.1016/j.scienta.2011.01.035

Vera, J., Abrisqueta, I., Abrisqueta, J., Ruiz-Sánchez, M., 2013. Effect of deficit irrigation on early-maturing peach tree performance. Irrig. Sci. 31, 747-757. doi:10.1007/s00271-012-0358-9

Verma, M., Thakur, B., Bhandari, A., 2007. Effect of drip irrigation and polyethylene mulch on yield, quality and water-use efficiency of peach cv., July Elberta. INDIAN J. Hortic. 64, 406-409.

Williamson, J.G., Crane, J.H., 2010. Best Management Practices for Temperate and Tropical/Subtropical Fruit Crops in Florida: Current Practices and Future Challenges. HortTechnology 20, 111-119.

Worthington, J.W., Lasswell, J.L., 1994. Peach tree response to trickle irrigation in Texas, in: Worthington, J.W. (Ed.), Microirrigation for Fruit Crops, Bull 378. Southern Cooperative Series, Texas AES, Texas A\&M University, pp. 17-30.

Zarini, R.L., 2014. Energy Consumption and Economic Analysis for Peach Production in Mazandaran Province of Iran. The experiment, International Journal of science and technology 20, 1427-1435. 